\title{
ANALITIKA
}

Available online http://ojs.uma.ac.id/index.php/ analitika

\section{Community Resillience Pada Penyintas Bencana Alam di Provinsi Yogyakarta}

\section{Community Resillience On Natural Disaster Survivors in Yogyakarta Province}

\author{
Zarina Akbar, Iriani Indri Hapsari, Burhanuddin Tola \\ Universitas Negeri Jakarta, Indonesia \\ *Corresponding author: E-mail: zarinaakbar@yahoo.com
}

\begin{abstract}
Abstrak
Jurnal ini menyajikan penerapan prinsip-prinsip inti dan nilai pendekatan ketahanan masyarakat di provinsi Yogyakarta. Model program digambarkan dalam situasi masyarakat dan kondisi pasca bencana untuk menyarankan cara untuk menumbuhkan ketahanan masyarakat. Ketahanan masyarakat mencakup kesiapan individu serta membangun konteks sosial yang mendukung masyarakat untuk bertahan dan pulih dari bencana. Peserta diambil dari penghuni Cangkringan kabupaten Provinsi DIY. Dalam penelitian ini juga diteliti tantangan dalam mengintegrasikan model ketahanan masyarakat untuk merangsang lebih banyak kesadaran bencana dan pentingnya pengembangan untuk evaluasi model ini di masyarakat. Tujuannya juga untuk melihat di mana kondisi bencana alam dapat dianggap sebagai jendela kesempatan bagi ketahanan masyarakat yang berkelanjutan dalam masyarakat.
\end{abstract}

Kata Kunci: Ketahanan Masyarakat, Korban Bencana Alam, Bencana Alam

\begin{abstract}
This journal presents the implementation of core principles and value of community resillience approach in Yogyakarta province. Model program is described in situations of community and conditions post disasters to suggest ways to foster community resilience. Community resilience encompasses individual preparedness as well as establishing a supportive social context in communities to withstand and recover from disasters. Participants were drawn from the inhabitants of Cangkringan districts Yogyakarta Province. In this research also examine the challenges of integrating model of community resillience to stimulate more disaster awareness and importance of developing for evaluation this model in society. The goal is also to see under which conditions natural disasters can be considered windows of opportunity for sustainability community resilience in society.
\end{abstract}

Keywords: Community Resillience, Disaster Survivors, Natural Disaster

How to Cite: Akbar, Z., Hapsari, I. I., Tola, B. (2017), Community Resillience Pada Penyintas Bencana Alam di Provinsi Yogyakarta, ANALITIKA, Vol 9 (2): 76 - 84 
Zarina Akbar, Iriani Indri Hapsari, Burhanuddin Tola, Community Resillience Pada Penyintas Bencana Alam di Provinsi Yogyakarta

\section{PENDAHULUAN}

Letak geologis negara Indonesia yang berada pada pertemuan tiga lempeng bumi yang aktif di dunia yaitu lempeng Indo-Australian di bagian selatan, lempeng Euro-Asian di bagian utara, dan lempeng Pasifik di bagian timur. Ketiga lempeng tersebut saling bergerak satu sama lainnya sehingga menyebabkan wilayah Indonesia aktif secara tektonik maupun vulkanik (National Agency for Disaster Management, 2010). Bencana alam hampir terjadi setiap tahunnya di Indonesia, salah satunya yang terjadi di Provinsi Yogyakarta pada bulan Mei 2006 dan bulan Oktober 2010 ketika dua bencana besar terjadi yaitu bencana gempa bumi di daerah Bantul dan bencana erupsi Gunung Merapi di daerah Cangkringan Sleman.

Gempa bumi yang melanda Propinsi Yogyakarta terjadi pada tanggal 27 Mei 2006. Kekuatan gempa adalah 5,9 pada Skala Richter. Pusat gempa di Samudra Indonesia kedalaman $16 \mathrm{~km}$ dari permukaan laut. Epicentrum gempa pada posisi 8,26 Lintang Selatan dan 110.310 Bujur Timur, atau kira-kira berada pada 37 kilometer sebelah selatan dari kota Yogyakarta. Gempa tersebut menyebabkan banyak korban dan kerusakan fisik bangunan rumah terutama di daerah Bantul sebanyak 4.143 orang meninggal, 12.026 orang terluka, 71.763 rumah rata tanah, 71.372 rumah rusak berat, dan 73.669 rumah rusak sedang (Media Center Gempa Yogya, 2006).

Bencana lainnya yang terjadi yaitu Erupsi Merapi yang terjadi di Provinsi Yogyakarta antara bulan oktober dan november 2010. Erupsi ini merupakan yang terparah sejak erupsi yang terjadi pada tahun 1870, menyebabkan banyak kerusakan dan kehilangan. Bencana ini menjadi yang terburuk karena sebanyak 32 desa dengan populasi lebih dari 70.000 orang meninggalkan rumah mereka. Berdasarkan data statistik dari Badan Nasional Pengendalian Bencana (BNPB), jumlah korban di Provinsi Yogyakarta sebanyak 277 orang meninggal dan 12.839 orang mengungsi. Erupsi merapi 2010 ini menyebabkan banyak kerusakan fisik pada berbagai sektor antara lain infrastruktur, sosial, dan ekonomi. Bencana menghancurkan banyak infrastruktur fisik seperti rumah, tempat publik, sekolah, instalasi publik seperti air dan listrik. Data dari BNPB bahwa lebih dari 2.636 unit rumah di Provinsi Yogyakarta yang rusak berat, 156 rumah rusak sedang, dan 632 rumah rusak ringan. Total adalah 3.424 rumah di Provinsi Yogyakarta yang mengalami kerusakan akibat dari bencana erupsi Merapi (BNPB, 2010).

Bencana menimbulkan banyak kerusakan dan perubahan bagi masyarakat yang menjadi korbannya. Upaya untuk membangun atau meningkatkan potensi ketahanan dalam masyarakat untuk mengatasi segala dampak perubahan yang ditimbulkan oleh bencana menjadi sangat penting artinya. Potensi ketahanan dalam masyarakat tersebut dinamakan resiliensi pada masyarakat. Resilensi mayarakat (community resilience) merupakan upaya untuk mengatasi, menghadapi, dan mitigasi stres yang dimunculkan oleh kejadian traumatik bencana (Chandra, Williams, Plough, Stayton, Wells, Horta, and Tang, 2013). Upaya pengembangan resiliensi pada masyarakat pasca bencana dinilai belum menjadi fokus konsentrasi 
Zarina Akbar, Iriani Indri Hapsari, Burhanuddin Tola, Community Resillience Pada Penyintas Bencana Alam di Provinsi Yogyakarta

sampai dengan saat ini, meskipun hal ini menjadi sangat penting artinya untuk dikembangkan di masyarakat.

Penelitian pendahuluan yang telah dilakukan oleh Akbar (2016) menemukan beberapa aspek psikologis yang menjadi faktor protektif yang mempengaruhi keadaan psikologis jangka panjang setelah bencana pada para survivors di Provinsi Yogyakarta. Faktor-faktor tersebut antara lain dukungan sosial, spiritualitas, pengatasan masalah (coping) yang efektif, dan pengalaman bencana yang dialami (disaster experience). Faktor-faktor psikologis ini dapat dikembangkan lebih lanjut menjadi keterampilan psikologis yang kemudian dapat dibangun menjadi strength untuk meningkatkan community resilience.

Penelitian-penelitian yang dilakukan mengenai komunitas dalam konteks kebencanaan di Provinsi Yogyakarta antara lain penelitian oleh Rakhman dan Kuswardhani (2012) mengenai pemberdayaan kearifan lokal sebagai model masyarakat tangguh menghadapi bencana menemukan bahwa nilai-nilai kearifan lokal seperti nrimo, ngaruhke, dan gotong royong dapat diberdayakan sebagai modal ketangguhan masyarakat dalam menghadapi bencana gempa bumi di Yogyakarta. Suharta, Prasetya, dan Tohani (2014) menemukan model konseptual komunitas sadar bencana yang terintegrasi dengan PKBM sebagai satuan pendidikan nonformal yang ada di masyarakat khususnya di tingkat desa. Dari beberapa penelitian tersebut dapat dilihat bahwa fokus dari model komunitas masyarakat pasca bencana yang telah ada baru terbatas pada model yang sifatnya konseptual, belum adanya model yang bersifat integrated karena hanya spesifik pada beberapa aspek tertentu saja misalnya aspek pendidikan, serta juga belum memfasilitasi aspek lainnya yang dinilai penting dalam komunitas misalnya upaya memfasilitasi kelompok risk and vulnerability berdasarkan personal/psychological strength di masyarakat tersebut. Penellitianpenelitian mengenai model community resilience juga dinilai masih terbatas di Indonesia, dibandingkan di negara-negara lain dimana community resilience sudah banyak dikembangkan. Penelitian dengan topik pengembangan model community resilience untuk meningkatkan disaster awareness pada masyarakat pasca bencana ini menjadi sangat penting artinya.

Hasil penelitian yang dilakukan oleh Akbar (2016) menemukan aspek-aspek psikologis yang menjadi faktor protektif yang mempengaruhi keadaan psikologis jangka panjang setelah bencana pada para survivors di Provinsi Yogyakarta. Faktorfaktor tersebut antara lain dukungan sosial, spiritualitas, pengatasan masalah (coping) yang efektif, dan pengalaman bencana yang dialami (disaster experience). Faktor-faktor psikologis ini dapat dikembangkan lebih lanjut menjadi keterampilan psikologis yang kemudian dapat dibangun menjadi kekuatan untuk meningkatkan community resilience.

Penelitian-penelitian mengenai community resilience banyak dikembangkan di negara-negara lain. Penelitian yang dilakukan oleh Fois dan Forino (2014) menjelaskan mengenai pengembangan community resilience post-disaster pada desa di wilayah Pescomaggiore, Italia setelah mengalami 
Zarina Akbar, Iriani Indri Hapsari, Burhanuddin Tola, Community Resillience Pada Penyintas Bencana Alam di Provinsi Yogyakarta

kejadian bencana gempa bumi L'Aquila pada tahun 2009. Bencana alam yang terjadi menjadi peluang untuk pengembangan community resilience pada masyarakat di daerah tersebut. Penelitian yang dilakukan oleh Wells, Tang, Lizaola, Jones, Brown, Stayton, Williams, Chandra, Eisenman, Fogleman, \& Plough (2013) menjelaskan mengenai program action community resilience pada masyarakat di daerah Los Angeles Amerika. Program community resilience ini dilakukan untuk meningkatkan disaster resiliency pada masyarakat pasca bencana yang selanjutnya dikembangkan menjadi kebijakan nasional di Los Angeles. Program pengembangan community resilience ini memerlukan waktu sekitar 3 tahun. Studi dari Colten, Grimsmore, dan Simms (2015) menemukan bahwa masyarakat di daerah pesisir di Lousiana Amerika yang menjadi korban dari bencana badai dan juga tumpahan minyak di pantai mengembangkan model community resilience setelah kejadian bencana tersebut. Pengembangan model community resilience didasarkan pada nilai-nilai dan pengetahuan lokal masyarakat setempat, aktivitas yang meningkatkan resiliensi masyarakat, program eksternal yang berkaitan dengan mitigasi bencana, dan program recovery post-disaster.

Grotberg (1995) menyatakan bahwa resiliensi adalah kemampuan seseorang untuk menilai, mengatasi, dan meningkatkan diri ataupun mengubah dirinya dari keterpurukan atau kesengsaraan dalam hidup. Karena setiap orang itu pasti mengalami kesulitan ataupun sebuah masalah dan tidak ada seseorang yang hidup di dunia tanpa suatu masalah ataupun kesulitan. Dari berbagai pengertian resiliensi di atas dapat disimpulkan bahwa resiliensi adalah kemampuan untuk mengatasi, meningkatkan diri, serta bertahan dan tidak berputus asa dari peristiwa buruk atau musibah. Selain itu, kesuliatn yang terjadi bisa diambil hikmah untuk bisa bangkit kembali.

Komunitas masyarakat mempunyai peranan penting dalam proses resiliensi bencana. Community resilience merupakan respon terhadap bencana yang memfokuskan pada keseimbangan di dalam masyarakat antara kebujakan intervensi dari institusi formal yang bersifat top-down sampai dengan memfasilitasi kebutuhan yang menjadi harapan masyarakat di bawah (grassroot). Community resilience tidak hanya bersifat top down aturan kebijakan yang sifatnya formal, tetapi juga menekankan pada proses yang sifatnya bottom up pada proses yang otonom berdasarkan kemampuan, keterampilan, dan aksi perilaku yang dimunculkan oleh masyarakat di daerah tersebut (Lewis and Kelman, 2010; Murphy, 2007). Community resilience mengakar pada kapasitas masyarakat untuk memperbaiki infrastruktur sosial, inisatif dari masyarakat, serta untuk mengelola sumber daya manusia dan sumber daya lokal masyarakat (Sefyang, 2010). Community resilience merupakan sebuah proses dan bukanlah suatu outcome (Manyena, 2006).

\section{METODE PENELITIAN}

Penelitian ini dilakukan di Desa Kaliadem yang merupakan salah satu desa yang merasakan langsung (affectedness) 
Zarina Akbar, Iriani Indri Hapsari, Burhanuddin Tola, Community Resillience Pada Penyintas Bencana Alam di Provinsi Yogyakarta

terparah dari bencana Erupsi Merapi Yogyakarta. Sampel dalam penelitian ini sebanyak 150 warga yang terdiri dari orang dewasa (perempuan dan laki-laki), anak remaja dan lansia. Terdapat $60 \%$ laki-laki dan $40 \%$ perempuan. Untuk menggali data dalam penelitian ini menggunakan kuesioner yang disusun oleh peneliti dengan teknik wawancara terbuka.

\section{HASIL DAN PEMBAHASAN}

Dalam penelitian ini berdasarkan hasil wawancara didapatkan data bahwa mereka ada pihak-pihak yang bertanggungjawab dalam kesiapsiagaan bencana/ tanggap darurat yakni seperti kepala Dukuh, RT, RW, pemuda dan kader dari masyarakat. Pihak-pihak tersebut berinteraksi atau berkomunikasi dengan pihak-pihak seperti departemen kesehatan tingkat lokal, kantor manajemen bencana nasional, tim SAR dan lainnya seperti pemerintah Yogyakarta. Masyarakat desa Kaliadem yang memiliki akses ke internet hanya sedikit. Masyarakat memperoleh informasiinformasi terkait kebencanaan dari keluarga dan teman, TV, pelatihan yang diadakan oleh BPBD maupun LSM, dan dari tokoh masyarakat di desa tersebut.

Bencana utama yang dihadapi oleh masyarakat adalah gunung meletus atau erupsi Merapi. Ketika bencana erupsi gunung Merapi yang terjadi pada tahun 2010 silam, masalah terkait kesehatan yang dihadapi oleh masyarakat adalah adanya kontaminasi air, pusing-pusinng, pilek, demam, dan beberapa ada yang terkena demam berdarah. Berdasarkan pengalaman masyarakat desa Kaliadem terkait bencana erupsi gunung Merapi, kelompok masyarakat yang paling terkena dampaknya adalah orangtua dan anakanak. Masyarakat berdasarkan pengalaman mempunyai tantangan yang dihadapi yakni sulit menentukan arah untuk lari dan bingung mengungsi kemana karena adanya perbedaan arah jalan ke pengungsian serta bingung ketika ada awan panas. Kemudian paska bencana, tantangan yang dihadapi masyarakat adalah dulu uang bukan segalanya sekarang jadi segalanya karena dulu tidak perlu membeli sayur-mayur sekarang perlu, dan memikirkan kehidupan anak serta cucu ke depan karena harta benda banyak yang habis.

Selanjutnya masyarakat mempunyai rencana penanggulangan bencana yakni menyiapkan teknis-teknis dalam menanggulangi bencana yakni adanya informasi dari pemerintah mengenai jalur evakuasi, transportasi, pemantauan kondisi merapi, pemnatauan jarak luncur, menyiapkan tempat pengungsian, dan yang terpenting masyarakat mengikuti instruksi Pak Dukuh. Di dalam masyarakat, yang berpartisipasi dalam pengembangan perencanaan upaya penaggulangan bencana adalah Pak Dukuh, RT, RW, kader-kader masyarakat, dan pemuda. Di luar masyarakat yang membantu untuk mempersiapkan dan menerapkan rencana penanggulangan bencana tersebut ada pemerintah nasional dan sukarelawan. Rencana penanganan bencana mempunyai komponen tertentu pada aspek kesehatan yakni cara-cara pertolongan pertama dan cara menangani ibu hamil. Dengan adanya perencanaan penanggulangan bencana, masyarakat menyatakan bahwa mereka dibuat menyadari isi dari perencanaannya tersebut dengan cara diadakannya 
Zarina Akbar, Iriani Indri Hapsari, Burhanuddin Tola, Community Resillience Pada Penyintas Bencana Alam di Provinsi Yogyakarta

pelatihan. Selain itu, masyarakat juga menyatakan bahwa mereka sudah sadar karena juga sudah berpengalaman dalam menghadapi bencana.

Menurut masyarakat pemerintah sudah menghasilkan bahan informasi tentang kesehatan, kesiapsiagaan bencana dan tanggap bencana yang dilakukan dengan adanya pelatihan-pelatihan. Masyarakat umum dapat mengerti informasi-informasi yang diberikan kecuali para lansia yang kurang dapat memahami isi dari informasi-informasi terkait kebencanaan. Tentunya informasiinformasi yang diberikan dapat membantu masyarakat untuk mempersiapkan dan menanggapi bencana. Masyarakat dapat menerima informasi terkait bencana melalui pelatihan dan televisi. Untuk kondisi darurat terkait bencana masyarakat mendapat informasi dari sirine, pengumuman di mushola, dari kepala dukuh, dari keluarga, tetangga, dan teman. Peringatan pertama atau informasi terkait bencana lainnya dibagikan atau disebarluaskan ke masyarakat melalui sirine dan HT.

Berdasarkan pengalaman dari bencana yang dialami dulu, rata-rata masyarakat mempersiapkan atau menanggapi bencana tersebut dengan menyiapkan dokumen-dokumen penting, menyiapkan transportasi, uang dan pakaian, Namun ada beberapa masyarakat yang lagsung lari menyelamatkan diri karena tidak sempat untuk menyiapkan dokumen. Kemudian terkait hasil dari upaya kesiapsiagaan dan upaya tanggap bencana adalah masyakarat dapat menyiapkan dokumen-dokumen penting, jika terjadi sesuatu yang tidak diinginkan masyarakat bisa langsung berkumpul dan bisa mengambil langkah selanjutnya sesuai himbauan, serta keluarga dapat selamat.

Masyarakat tidak mengetahui ada atau tidaknya kebijakan mengenai kebencanaan di negara Indonesia yang diatur oelh undang-undang. Masyarakat tidak mempunyai kebijakan sendiri terkait kesiapsiagaan dan tanggap bencana karena menurut pada pimpinan. Langkah berikutnya yang dianjurkan untuk mengurangi risiko kesehatan dalam keadaan darurat dan untuk meningkatkan kesiapsiagaan bencana adalah menyiapkan masker agar terhindar dari pusing, pilek, demam, memisahkan ruang pengungsian antar anak-anak dan lansia, serta menyiapkan obat-obatan dan makanan bergizi. Menurut masyarakat, pihak yang bertanggung jawab untuk memulai proses perencanaan adalah anggota masyarakat dan pemimpin masyarakat. Kemudian yang harus terlibat dalam perencanaan langkah berikutnya untuk meningkatkan kesiapsiagaan bencana dan untuk mengurangi risiko kesehatan adalah berbagai pihak terkai seperti pemerintah, pimpinan masyarakat, LSM, pukesmas, dan dokter.

Di masyarakat terdapat pendidikan ketangguhan menghadapi bencana yakni berupa simulasi dan masyarakat menilai hal tersebut cukup efektif. Untuk lebih spesifiik seperti ketangguhan psikis sebelum bencana tidak ada, namun paska bencana ada. Penanganan pada saat bencana kemarin terhadap masyarakat yang beresiko (lansia, anak-anak, masyarakat berkebutuhan khusus) diamankan terlebih dahulu pada titik yang aman dan di tempat terpisah bagi balita. Penanganan terhadap masyarakat yang 
berisiko (lansia, anak-anak, masyarakat berkebutuhan khusus) pada bencana tahun 2010 silam, banyak masyarakat menilai sudah baik namun ada yang mengusulkan untuk kedepannya lansia juga dipisah ruang pengungsiannya. Selain itu, tempat pengungsian terhadap semua masyarakat lebih bersih lagi karena dulu ada beberapa masyarakat yang terkena demam berdarah.

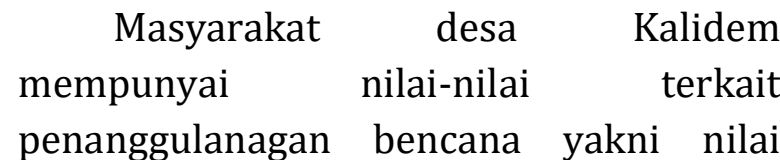
religius yakni menyerahkan kepada Allah, percaya Allah bahwa rezeky sudah diatur, dan selalu merasa dilindungi oleh Allah. Kemudian nilai kemasyarakatan yakni kekompakan yang biasa disebutkan dengan kalimat "mangan ora mangan sing penting bareng lan urip mati bareng" yang artinya makan tidak makan, hidup dan mati yang penting bersama. Selain itu, kompak saling tolong-menolong.

Masyarakat daerah Kaliadem mayoritas bekerja sebagai petani dan peternak. Pagi hari masyarakat bekerja memerah susu sapi, siang hari meladang dan mencari rumput, serta sore hari memerah susu sapi. Masyarakat mendapatkan penghasilan juga melalui penjualan hasil berkebun. Masyarakat menerapkan nilai hidup "guyub" yaitu saling membantu menolong. Hal ini terlihat dari perilaku saling membantu, membahagiakan, serta saling bertukar hasil panen satu dengan lainnya. Terdapat aktivitas ritual yang diadakan masyarakat desa agar tidak terjadi bencana erupsi. Sebelum bencana terjadi masyarakat sedang melakukan aktivitasnya masingmasing. Setelah mendengar suara gemuruh yang sangat kuat, dan tak lama setelah itu para relawan dan TNI dating menjemput untuk diungsikan. Proses pengungsian relawan dan TNI menjadikan lansia, ibu hamil dan balita sebagai prioritas dengan cara mengangkut/membawa lansia terlebih dahulu dengan menggunakan truk. Tokohtokoh yang terlibat dalam penanggulangan bencana diantaranya kepala RT, RW, dan Kepala Dukuh.

Setelah mengalami bencana Erupsi Merapi terjadi perubahan pada masyarakat. Hal ini disebabkan oleh tidak adaya tempat untuk bercocok tanam atau beternak kembali. Kehidupannya hanya menggantungkan pada bantuan dari pemerintah. Masyarakat desa kaliadem menjadi sangat kompak dalam adanya penanggulangan bencana. Terdapat prinsip yang selalu dipegang oleh masyarakat yaitu "mati urip barengdadi siji dan maem ra maem bareng". Arti dari bahasa tersebut adalah hidup atau mati, makan atau tidak makan masyarakat selalu bersama. Perubahan yang terjadi yang lainnya adalah dalam hal kegiatan religiusitas. Banyak warga yang sebelumnya tidak sholat dan setelah teradi bencana menjadi sholat. Selain itu masyarakat banyak mengadakan kegiatan pengajian.

\section{SIMPULAN}

Berdasarkan hasil studi di atas, dapat dikembangkan model konseptual kerangka community resilience pada masyarakat pasca bencana yaitu adanya partnership and institusional(hubungan formal dan informal antara lembagalembaga yang terkait dan community based organizations), education and engagement (aktivitas yang dilakukan 
Zarina Akbar, Iriani Indri Hapsari, Burhanuddin Tola, Community Resillience Pada Penyintas Bencana Alam di Provinsi Yogyakarta

\begin{tabular}{lrr} 
mengenai disaster prepared dan & \multicolumn{2}{c}{ datif } \\
community & resilience, perspektif \\
mengenai & kemampuan & community \\
resilience dan kemampuan untuk & un \\
mengedukasi & masyarakat), available \\
resources & & (nilai-nilai
\end{tabular}
personal.psychological strength yang akan menjadi kekuatan di masyarakat, ketersediaan sumber daya dari berbagai pihak yang dapat menjadi kekuatan di masyarakat), serta risk and vulnerability(aktivitas yang berkaitan dengan disaster preparedness, komunikasi dan respon yang diberikan, pelatihan, dan edukasi, dan community preparedness terhadap kelompok yang rentan dan beresiko seperti anak-anak, anak berkebutuhan khusus, gangguan jiwa dan lansia) yang akan dikaji dalam penelitian selanjutnya.

\section{DAFTAR PUSTAKA}

Akbar, Z. (2016). Post-Traumatic Growth: Long Term Psychological Conditions Among Disaster Survivors in Yogyakarta Indonesia. Dissertation. University of Leipzig, Germany.

BNPB. (2010). National Disaster Management Plan 2010-2014. Jakarta, Indonesia: BNBP.

Chandra, A., Williams, M., Plough, A., Stayton, A., Wells, K., Horta, M., \& Tang, J. (2013). Getting Actionable About Community Resilience: The Los Angeles County Community Disaster Resilience Project. American Journal of Public Health, eı-e9.

Colten, C. E., Grimsmore, A. A., \& Simms, J. R. (2015). Oil Spills And Community Resilience: Uneven Impacts And Protection In Historical Perspective. Geographical Review, 105(4), 391-407.

Fois, F \& Forino, G. (2014). The Self-Built Ecovillage In L'Aquila, Italy: Community Resilience As A Grassroots Response To Environmental Schock. Disasters, 38(4), 719-739.

Glantz, M. \& Johnson, J. (2002). Resilience and development positive life adaptation. USA: Kluwer Academic Publisher
Grothberg, E. (1995). A Guide to Promoting Resilience in Children: Strengthening the Human Spirit. The Series Early Childhood Development : Practice and Reflections. Number8. The Hague : Benard van Leer Voundation.

Grothberg, E. (1999). Tapping Your Inner Strength, Oakland, CA : New Harbinger Publication, Inc.

Kirby, A. (2003). Redefining Social and Environmental Relations at the Ecovillage at Ithaca: A Case Study. Journal of Environmental Psychology, 23, 323-332.

Lewis, J., \& Kelman, I. (2010). Places, People, And Perpetuity: Community Capacities in Ecologies of Catastrophe. ACME: An International E-Journal for Critical Geographies, 9(2), 191-220.

Maddi, S. \& Khoshaba, D. (2005). Resilience at work: How to succed no matter what life throws at you. USA: American Management Association.

Manyena, S. B. (2006). The Concept of Resilience Revisited. Disasters, 30(4), 433-450.

Media Center Gempa Yogya. (2006). Gempa Bumi Yogyakarta 2006. www.mediacenter.or.id.

Murphy, B. L. (2007). Locating Social Capital in Resilient Community-Level Emergency Management. Natural Hazards, 41(2), 297315 .

National Agency for Disaster Management. (2010). Merapi Eruption Disaster in Yogyakarta and Central Java Province. Jakarta, Indonesia. Jakarta, Indonesia: National Agency for Disaster Management.

Norman, E. (2000). Resiliency enhancement: Putting the strength perspective into social work practice. New York: Columbia University Press.

Rakhman, A. N., \& Kuswardani, I. (2012). Studi Kasus Gempa Bumi Yogyakarta 2006: Pemberdayaan Kearifan Lokal Sebagai Modal Masyarakat Tangguh Menghadapi Bencana. Prosiding. Seminar Nasional Aplikasi Sains dan Teknologi (SNAST) Periode III 3 November 2012, Yogyakarta.

Reivick, K \& Shatte, A. (2002). The Resilience Factor: 7 Essential Skills for Overcoming Life's Inevitable Obstacles. New york: Broadway Books

Sefyang, G. (2010). Community Action for Sustainable Housing: Building A LowCarbon Future. Energy Policy, 38(12), 76247633. 
Zarina Akbar, Iriani Indri Hapsari, Burhanuddin Tola, Community Resillience Pada Penyintas Bencana Alam di Provinsi Yogyakarta

Suharta, R., Prasetyo, I., \& Tohani, E. (2014). Pengembangan Komunitas Sadar Bencana Terintegrasi "PKBM" Di Kabupaten Bantul Dan Sleman. Laporan Penelitian Terapan. Fakultas Ilmu Pendidikan, Universitas Negeri Yogyakarta.

Wells, K., Tang, J., Lizaola, E., Jones, F., Brown, A., Stayton, A., Williams, M., Chandra, A., Einsenman, D., Fogleman, S., \& Plough, A. (2013). Applying Community Engagement to Disaster Planning: Developing the Vision and Design for the Los Angeles County Community Disaster Resilience Initiative. American Journal of Public Health, ei-eg.

Zhou, H. (2010). Resilience to Natural Hazards: A Geographic Perspective. Natural Hazards, 53(1), 21-41. 